\title{
PESQUISA SOCIAL QUALITATIVA PARA COMPREENSÃO DA COVID-19
}

\author{
Social and qualitative research to understand the COVID-19 \\ Investigación social cualitativa para comprender la COVID-19
}

\author{
Maria Cecilia de Souza Minayo \\ Pesquisadora Emérita da Fundação Oswaldo Cruz \\ Email: maminayo@terra.com.br \\ https://orcid.org/0000-0001-6187-9301
}

A pesquisa qualitativa tem como matéria prima um conjunto de substantivos cujos sentidos se complementam: experiência, vivência, senso comum e ação que, por sua vez, expressam valores, crenças e representações sociais. O movimento que informa qualquer olhar ou análise por meio dessa abordagem, se baseia em três verbos: compreender, interpretar e dialetizar (Minayo, 2012; 2019). Qualquer questão humana pode ser objeto de estudos qualitativos. E essa utilidade é profundamente produtiva quando se trata de saúde ou doença, e se aplica como luva às questões relativas à COVID-19.

Enquanto o mundo biomédico mundial se instiga, investiga, pergunta-se e se desmente em relação ao novo coronavirus, até o momento, apenas algumas de suas descobertas e recomendações são consideradas seguras, assertivas e inquestionáveis: lavar as mãos e passar alcool gel nelas e nos lugares de contato, promover o confinamento em casa e manter o distanciamento social. O usar máscara, primeiro recomendado apenas para profissionais de sáude, passou a fazer parte desse consenso e se tornou universal. É preciso ressaltar que todos os procedimentos e práticas recomendadas são objeto das ciências sociais (e não das ciências biomédicas) e são tema preferencial da pesquisa qualitativa.

Enquanto os grandes pesquisadores das ciências hard observam o comportamento do vírus e buscam contratacá-lo com medicamentos e vacinas, eles próprios, cotidiana e rotineiramente repetem o mantra da necessidade da população agir com atitudes e práticas para conter a exposição e a contaminação pelo virus. Há neste momento histórico um encontro das ciências biomédicas com o comportamento coletivo. Ao lado da corrida e das perspectivas sobre medicamentos e vacinas eficazes, muitas perguntas que hoje nos afligem são parte das ciências soft e deveriam ser endereçadas aos sociólogos e antropólogos.

Eis algumas indagações que, em geral, nos fazemos: por que determinados países estão sendo capazes de agir de forma eficiente e conter o virus? por que em alguns luga- res a sociedade obedece às autoridades sanitárias e conseguem vencer a pandemia? Por que em outros contextos culturais é comum em determinados segmentos sociais e etários desconhecer as regras de prevenção, como se as pessoas fossem invenciveis? De onde vem o negacionismo das autoridades de alguns países? Que relação existe entre o exemplo negacionista, a assertividade das orientações e o alastramento dessa doença infecciosa? Quais as experiências vividas pelas pessoas que se curaram, que perderam seus entes queridos e que lições elas aportam para a sociedade? Que valores, opiniões e crenças atrapalham o enfretamento da pandemia e quais os que propiciam seu melhor enfrentamento? Como determinados grupos de pessoas (profissionais liberais, pessoas em home office, trabalhadores da indústria e dos serviços, casais, crianças, jovens, idosos estão vivenciando o confinamento social? Qual o sentido dessas experiências para o amanhã da sociedade? Como os trabalhadores das atividades essenciais estão se protegendo e vivenciando seus medos? Como as diferentes categorias de profissionais do setor saúde, atuando na linha de frente dos ambulatórios, hospitais e UTI, estão encarando sua missão neste momento tão difícil? O que eles teriam a dizer sobre o apoio material, profissional e humano que estão ou não recebendo? Como as mortes dos colegas os afetam? Em que a gestão da pandemia pelos profissionais de saúde poderia ajudar a aprimorar o SUS? Por que políticos e gestores, mesmo frente a uma doença tão cruel se corrompem e roubam o dinheiro que deveria ser dedicado a seu enfrentamento?

A lista de temas poderia continuar e bater em temas sociológicos indeclináveis como a exacerbação das desigualdades de classe, entre homens e mulheres, entre categorias de trabalhadores da saúde, dentre outras; as condições aglomeradas das habitações dos pobres; a falta de saneamento básico; e o uso político da pandemia à revelia das mortes e do sofrimento coletivo.

Em resumo, quero assinalar neste editorial que, se há um signficado nessa pandemia, é seu enorme potencial 
de levantar, do ponto de vista pessoal, muitas indagações sobre a precariedade de nossas vidas, de nossos comportamentos, de nossos relacionamentos, de nossos medos, inclusive, de nosso encontro inesperado com a morte. Do ponto de vista coletivo, ela ressalta a gravidade dos problemas sociais, a imensa quantidade de brasileiros sem proteção e desempregados, e nossos deficits culturais, educacionais e materiais.

Mas, eu não posso deixar passar despercebido que, do ponto de vista epistemológico, a COVID-19 provocou o encontro perfeito entre a macro e a micro realidade que a ciência pesquisa. $O$ virus acomete cada indivíduo em sua idiossincrasia: no que traz de medo e coragem, de resistência ou de entrega: o virus se adequa. Por isso, junto com os filósofos da teoria da complexidade, não vejo determinações e sim um movimento recursivo entre o biológico, o social e o emocional (Morin, 2000). É nessa corrente compreensiva que qualquer pesquisa qualitativa sobre o novo coronavirus precisa caminhar.

Nas experiências é preciso buscar o entendimento de como o indivíduo compreende a si mesmo e seu lugar no mundo, o que se expressa na linguagem organizada pela cultura, por meio do senso comum. O senso comum, diferentemente do definido pelo positivismo como "pré-conceito", é de um lado, a mola de ação dos seres humanos; de outro, a matéria prima da pesquisa social qualitativa. O conceito de ação aqui utilizado, está vinculado à noção de liberdade para agir, construir e transformar o mundo (Weber, 1994). Mundo esse que, para Heidegger (1988), não constitui um lugar e sim um complexo formado pela significação das experiências que fazem do ser humano um ser histórico.

O estudo das vivências trabalha com a reflexão sobre a experiência, o que depende da personalidade, da história existencial, da participação social e de outros elementos mais sutis que marcam a pessoa. Suas singularidades se expressam na experiência e na vivência de uma biografia que se desenvolve no contexto da história coletiva, comunitária e institucional (Bourdieu,1972). Por isso a primeira lição dialética aqui a celebrar é que a realidade humana é simultaneamente individual e social. Mas é igualmente parcial e inacabada, portanto, não pode existir pretensão de alcançar a verdade (Heidegger, 1988). É nesse domínio que se move a pesquisa qualitativa, em suas possibilidades e limitações para compreender e interpretar fenômenos tão complexos, tão mutantes, e tão metafóricos como o novo coronavirus.

\section{Descritores:}

Pesquisa qualitativa; COVID-19; Sociologia compreensiva.

Qualitative research; COVID-19; Comprehensive sociology.

Investigación cualitativa; COVID-19; Sociología comprensiva.

\section{Referências}

Bourdieu, P. (1972). Ésquisse d'une théorie de la pratique. Paris: Librairie Dorz.

Heidegger, M. (1988). Ser e tempo. Petrópolis: Editora Vozes.

Minayo, M.C.S. (2012). Análise qualitativa: teoria, passos e fidedignidade. Ciência \& Saúde Coletiva, 17,(3),621-626.

Minayo, M.C.S.; Costa, A.P. (2019). Técnicas que fazem uso da Palavra, do Olhar e da Empatia. Pesquisa qualitativa em ação. São Paulo: Hucitec.

Morin, E. (2000) A inteligência da complexidade. São Paulo: Peirópolis.

Weber, M. (1994). Economia e sociedade: fundamentos da sociologia compreensiva. Brasília: Editora Universidade de Brasilia. 